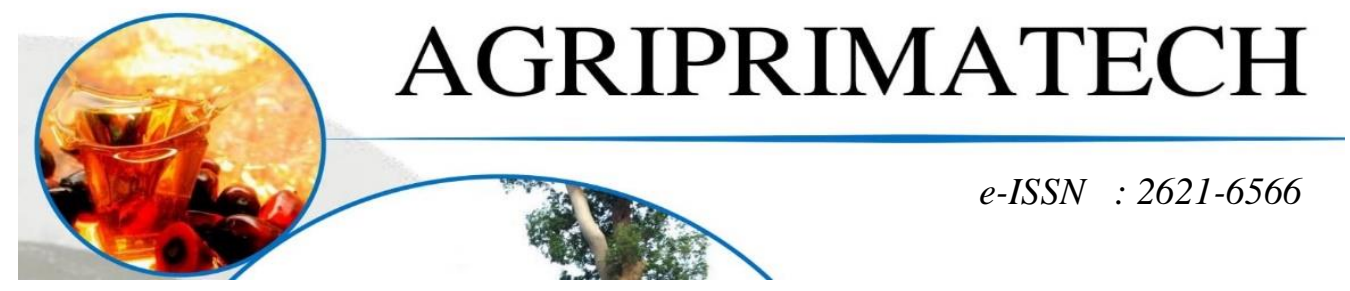

\title{
KARAKTERISTIK PETANI KELAPA SAWIT DI KABUPATEN LABUHAN BATU UTARA
}

\author{
MYRNA PRATIWI ${ }^{1}$, LAURA JUITA PINEM ${ }^{2}$ \\ 1,2 Fakultas Agroteknologi, Universitas Prima Indonesia, Sumatera Utara \\ Email: myrnapratiwi77@gmail.com
}

\begin{abstract}
ABSTRAK
Penelitian ini bertujuan untuk mengidentifikasi karakteristik petani kelapa sawit yang terdapat di Kabupaten Labuhan Batu Utara. Penelitian ini dianalisis dengan bantuan 200 responden. Metode yang digunakan dalam penelitian ini adalah analisis deskriptif. Hasil penelitian menunjukkan bahwa sebanyak 32 persen petani berada pada rentang usia 51-55 tahun, 36 persen memiliki pendidikan pada jenjang Sekolah Dasar (SD), 46 persen petani memiliki luas lahan sebesar 1-5 Ha, 33 persen petani telah berusahatani selama 0-5 tahun, 78 persen memiliki tanggungan sebanyak 1-5 orang dan seluruh petani memiliki lahan sendiri untuk berusahatani.
\end{abstract}

Kata kunci: Kelapa Sawit, Petani, Karakteristik, Analisis

\section{PENDAHULUAN}

Peningkatan jumlah lahan perkebunan kelapa sawit di Indonesia menunjukkan tren meningkat dari tahun ke tahun baik oleh perkebunan swasta, rakyat dan Negara. Peningkatan ini menjadikan kelapa sawit menjadi komoditas perkebunan unggulan Indonesia. Peningkatan luas lahan yang disumbangkan oleh perkebunan rakyat juga memiliki peran penting dalam dunia perkelapasawitan Indonesia. Peran petani kelapa kecil (petani rakyat) menjadi produsen kelapa sawit di Indonesia semakin lama menunjukkan angka yang meningkat. Pada tahun 2016 luas lahan perkebunan kelapa sawit yang dimiliki oleh petani rakyat sekitar 4,6 juta hektar dan meningkat dengan pesat dari tahun ke tahun hingga diestimasi pada tahun 2019 luas lahan dari petani rakyat di Indonesia

berada pada angka 5,9 juta hektar (Ditjetbun, 2018).

Dukungan teknis dan masukan produsen korporasi yang berada dalam luar lingkup Negara sering sekali tidak mencapai petani rakyat sehingga banyak petani yang menjalankan perkebunan yang dikelolanya dengan mandiri. Pengoperasian perkebunan yang dilakukan petani secara mandiri tesebut tidak hanya menjadikan petani sebagai produsen sawit dengan tingkat produktivitas rendah, tetapi juga seringkali mengoperasikan perkebunanannya tanpa kelayakan perizinan dan pada lahan yang secara legal atau pada tempat yang tidak boleh dibudidayakan. Faktor terpenting yang 
Agriprimatech

Vol. 3 No. 2, April 2020

mempengaruhi produktivitas kelapa sawit adalah mutu benih kelapa sawit. Namun ketersediaan benih sawit unggul bermutu tinggi yang bersertifikat tersebut sangat ditentukan oleh beberapa faktor seperti: jumlah benih sawit unggul yang dapat diproduksi, belum standarnya teknik budidaya yang diterapkan, keterbatasan modal dan pengetahuan manajemen, kurangnya wawasan/pengalaman petani dan kurangnya kesadaran akan pentingnya mutu dan produktifitas tanaman (Liwang et al., 2009).

Sumatera Utara merupakan salah satu propinsi yang memiliki luas lahan yang tinggi di Indonesia. Salah satu kabupaten di Sumatera Utara yang menempatkan kelapa sawit sebagai salah satu komoditas unggulan daerahnya adalah Kabupaten Labuhan Batu Utara. Banyak petani rakyat yang menggantungkan kehidupan mereka pada komoditas kelapa sawit. Ada sekitar 15.960 petani yang berkecimpung pada sektor ini. Tetapi produktifitas dari kelapa sawit yang dikelola oleh petani belum maksimal, hal ini ditunjukkan melalui data dari Direktorat Jenderal Perkebunan bahwa pada tahun 2016, Kabupaten Labuhan Batu Utara mempunyai luas area kelapa sawit sebesar 68.178 hektar dengan produktifitas $3.058 \mathrm{~kg} / \mathrm{ha}$ sedangkan data dari lembaga yang sama menunjukkan bahwa di Sumatera Utara perkebunan yang dikelola oleh perkebunan swasta dan negeri bisa mencapai produktifitas $4.415 \mathrm{~kg} / \mathrm{ha}$. Salah satu alasan yang menjadi kemungkinan belum maksimalnya produktifitas kelapa sawit petani di Kabupaten Labuhan Batu Utara adalah karena penggunaan benih palsu atau benih yang tidak terjamin mutunya. Hal senada telah dianalisis Kariyasa (2015), dalam jurnalnya mengatakan bahwa petani yang menggunakan benih bersertifikat mampu mengembalikan modal yang diinvestasikan lebih cepat jika dibandingkan dengan petani yang menggunakan benih non sertifikat.
e-ISSN :2621-6566

Petani rakyat merupakan populasi yang heterogen sehingga untuk mengintervensi petani melalui program bantuan teknis untuk memajukan perkebunan rakyat memerlukan pendekatan yang lebih terencana. Pendekatan yang lebih terencana tersebut diharapkan dapat menangani masalah produktifitas, keberlanjutan dan legalitas dari perkebunannya. Tetapi pendekatan yang akan dilakukan bukanlah hal yang mudah karena, ketiadaan pengetahuan komprehensif dasar mengenai karakteristik petani rakyat dan tantangan spesifiknya melemahkan upaya formulasi dan skala pendekatan yang tepat. Hal tersebut mendorong peneliti untuk melakukan penelitian terhadap karakteristik dari petani kelapa sawit yang berada di Kabupaten Labuhan Batu Utara dan dengan penelitian ini diharapkan karakteristik dari petani dapat dilihat dan pendekatan yang tepat dapat direncanakan pada tahap berikutnya.

\section{METODE PENELITIAN}

Jumlah sampel yang digunakan dalam penelitian ini adalah 200 responden. Jumlah sampel ini didapat dengan merujuk kepada Rumus Slovin yang digunakan untuk menentukan ukuran minimal sampel yang dibutuhkan dari suatu populasi sehingga mendapatkan sampel yang mewakili populasi.

Dimana:

$$
\mathrm{n}=\frac{N}{1+\epsilon^{2} N}
$$

$\mathrm{n}$ = Besar sampel

$\mathrm{N}=$ Besar populasi

$\epsilon=$ Batas toleransi kesalahan (error tolerance) 10 persen

Data Primer yang diambil dari respoden berupa karakteristik petani kelapa sawit yang mencakup tentang umur, tingkat pendidikan, luas lahan pengalaman berusahatani, dan kepemilikan lahan. Data yang diperoleh kemudian dianalisis secara deskriptif dengan dukungan tabulasi sederhana. 
Analisis deskriptif bertujuan menyajikan data mentah yang didapat dalam penelitian menjadi lebih mudah untuk dipahami dengan membentuknya menjadi informasi yang ringkas. Analisis ini diharapkan dapat memberikan gambaran karakteristik petani kelapa sawit di Kabupaten Labuhan Batu Utara.

\section{HASIL DAN PEMBAHASAN}

\section{Karakteristik Petani Kelapa Sawit}

Karakteristik petani kelapa sawit diperlukan dalam penelitian ini untuk mengetahui sejumlah ciri atau sifat yang dimiliki oleh petani kelapa sawit. Mengetahui karakterisktik dari petani merupakan salah satu informasi yang dibutuhkan produsen untuk menentukan segmentasi, target pasar dan positioning yang tepat (Kotler, 2016). Karakteristik responden yang digunakan dalam penelitian ini adalah umur, tingkat pendidikan, lama berusaha tani, luas lahan, status kepemilikan dan jumlah tanggungan keluarga.

\section{Umur}

Umur merupakan salah satu faktor yang berpengaruh bagi petani dalam mengelola usahatani dikarenakan semakin tua umur petani maka keadaan fisik petani akan semakin lemah dan begitu sebaliknya bila umur petani masih muda maka kemampuan fisik petani semakin besar untuk mengelola usahataninya. Bertolakbelakang dengan hal tersebut bila semakin tua umur petani maka pengalaman petani dalam menjalankan usahatani juga relatif semakin banyak dan sebaliknya saat usia petani masih muda maka pengalaman dalam berusahatani relatif sedikit.

Bakir dan Maning (1984)
mengatakan bahwa umur produktif untuk bekerja di negara-negara berkembang pada umumnya adalah 1555 tahun. Tabel 1 menunjukkan bahwa persentase terbesar responden berada pada rentang umur 51-55 tahun, yaitu sebesar 32 persen. Menurut teori rentang usia itu masih berada pada usia produktif dimana pada usia produktif dan berpotensi untuk mengembangkan usahatani, meningkatkan hasil produksi dan pendapatannya. Pelatihan bagi petani dapat dilakukan pada petani yang masih muda untuk memperluas dan menambah pengetahuan mengenai teknik-teknik budidaya kelapa sawit yang benar termasuk penggunaan benih yang bermutu sehingga dengan pertambahan umur petani diharapkan produksi maksimal akan dicapai.

Tabel 1. Karakteristik Petani Kelapa Sawit menurut Kelompok Umur

\begin{tabular}{cccc}
\hline No & Kategori Umur (Tahun) & $\begin{array}{c}\text { Jumlah Responden } \\
\text { (Orang) }\end{array}$ & Persentase (\%) \\
\hline 1 & $31-35$ & 42 & 21 \\
2 & $36-40$ & 46 & 23 \\
3 & $41-45$ & 24 & 12 \\
4 & $46-50$ & 14 & 7 \\
5 & $51-55$ & 64 & 32 \\
6 & $>55$ & 10 & 5 \\
\hline & Jumlah & $\mathbf{2 0 0}$ & $\mathbf{1 0 0}$ \\
\hline
\end{tabular}

Tingkat Pendidikan

$\begin{array}{lr}\text { Pendidikan yang dimiliki oleh } \\ \text { petani diharapkan } & \text { mampu } \\ \text { mempermudah petani } & \text { dalam } \\ \text { mengadopsi teknologi dan } & \text { ketrampilan } \\ \text { manajemen dalam } & \text { mengelola }\end{array}$

usahataninya. Hal ini menunjukkan bahwa pendidikan merupakan salah satu penunjang dalam peningkatan produksi kelapa sawit yang diusahakan. Tabel 2 menunjukkan bahwa persentase tingkat pendidikan yang paling besar 
adalah Sekolah Dasar (SD), yaitu sebanyak 36 persen. Tingkat pendidikan petani memiliki pengaruh terhadap polapola pikir dan daya nalar petani, biasanya petani yang mengenyam pendidikan lebih tinggi akan mempunyai cara berpikir yang lebih rasional dalam bertindak dan menjalankan usahataninya. Hal ini senada dengan apa yang diutarakan oleh Afrizon (2012)

Tabel 2. Karakteristik Petani Kelapa Sawit menurut Kelompok Pendidikan

\begin{tabular}{clcc}
\hline No & Kategori Pendidikan & $\begin{array}{c}\text { Jumlah Responden } \\
\text { (Orang) }\end{array}$ & Persentase (\%) \\
\hline 1 & SD & 72 & 36 \\
2 & SMP & 37 & 18.5 \\
3 & SMA & 33 & 16.5 \\
4 & DIPLOMA & 7 & 3.5 \\
5 & SARJANA & 51 & 25.5 \\
\hline \multicolumn{2}{r}{ Jumlah } & $\mathbf{2 0 0}$ & $\mathbf{1 0 0}$ \\
\hline
\end{tabular}

\section{Lama Berusahatani}

Usahatani merupakan kegiatan usaha dimana pada kegiatan tersebut petani mengusahakan tanahnya dengan tujuan memperoleh hasil tanaman atau hewan tanpa mengurangi kemampuan tanah yang bersangkutan untuk memperoleh hasil selanjutnya. Pengalaman dalam berusahatani sangat mempengaruhi petani dalam menjalankan kegiatan usahatani dan hal tersebut dapat dilihat dari hasil produksi tanamannya.

Tabel 3 menunjukkan bahwa sebanyak 33 persen petani memiliki pengalaman usahatani selama $0-5$ tahun. Data ini menunjukkan bahwa sebanyak 33 persen petani memiliki pengalaman yang relatif belum lama dalam menjalankan usahataninya. Pengalaman yang semakin banyak diperoleh petani akan menaikkan minat terhadap usahatani dan dengan banyaknya pengalaman yang dimiliki akan melatih kemampuan dan kematangan petani dalam mempertimbangkan setiap langkah keputusan yang berkaitan dengan usahatani kelapa sawit yang sedang dijalankan termasuk peningkatan produksi. Hal yang sama juga dinyatakan oleh Edwina yang melakukan penelitian pada karakteristik petani kelapa sawit pada program Siska di Kabupaten Pelalawan.

Tabel 3. Karakteristik Petani Kelapa Sawit menurut Kelompok Lama Berusahatani

\begin{tabular}{cccc}
\hline No & $\begin{array}{c}\text { Lama Berusaha Tani } \\
\text { (Tahun) }\end{array}$ & $\begin{array}{c}\text { Jumlah Responden } \\
\text { (Orang) }\end{array}$ & Persentase (\%) \\
\hline 1 & $0-5$ & 66 & 33 \\
2 & $6-10$ & 56 & 28 \\
3 & $11-15$ & 27 & 13.5 \\
4 & $16-20$ & 18 & 9 \\
5 & $>20$ & 33 & 16.5 \\
\hline & Jumlah & $\mathbf{2 0 0}$ & $\mathbf{1 0 0}$ \\
\hline
\end{tabular}

\section{Luas Lahan}

Luas lahan merupakan salah satu faktor produksi penting dalam usahatani. Besar kecilnya lahan mempengaruhi besar kecilnya pendapatan yang diperoleh dari usahatani (Edwina, 2014. Sebanyak 200 responden ang dianalisis terdapat 46 persen dari responden yang memiliki lahan seluas 1-5 Ha dan sebanyak 30.5 persen petani memiliki luas lahan sebesar 6-10 $\mathrm{Ha}$. Luas lahan yang 
Agriprimatech

Vol. 3 No. 2, April 2020

e-ISSN :2621-6566

dimiliki oleh petani memungkinkan petani untuk berusahatani kelapa sawit lebih baik sehingga produksi yang

dicapai lebih tinggi dan hal ini akan berpengaruh langsung terhadap pendapatan yang dihasilkan petani.

Tabel 4. Karakteristik Petani Kelapa Sawit menurut Kelompok Luas Lahan

\begin{tabular}{cccc}
\hline No & Luas Lahan (Ha) & Jumlah Responden (Orang) & $\begin{array}{c}\text { Persentase } \\
(\%)\end{array}$ \\
\hline 1 & $1-5$ & 92 & 46 \\
2 & $6-10$ & 61 & 30.5 \\
3 & $11-15$ & 12 & 6 \\
4 & $>15$ & 35 & 17.5 \\
\hline & Jumlah & $\mathbf{2 0 0}$ & $\mathbf{1 0 0}$ \\
\hline
\end{tabular}

\section{Status Kepemilikan}

Status kepemilikan lahan seluruh petani responden yang dianalisis menunjukkan bahwa pengguna benih bersertifikat memiliki sendiri lahan yang mereka kelola. Tingginya status kepemilikan lahan yang dipunyai petani memungkinkan petani lebih leluasa dalam mengambil keputusan dalam berusahatani. Status kepemilikan lahan petani dapat dilihat pada Tabel 5 .

Tabel 5. Karakteristik Petani Kelapa Sawit menurut Kelompok Status Kepemilikan No Status Kepemilikan Jumlah Responden (Orang) Persentase

1 Sewa $\quad 200 \quad 100$

2 Milik Sendiri $\quad 0 \quad 0$

$\begin{array}{lll}\text { Jumlah } & 200 & 100\end{array}$

\section{Jumlah Tanggungan Keluarga}

Jumlah tanggungan keluarga yang dimaksudkan dalam penelitian ini adalah jumlah anggota keluarga yang masih menjado tanggungan keluarga tersebut, baik itu saudara kandung maupun tidak kandung yang tinggaldalam satu rumah namun belum bekerja. Semakin banyak jumlah tanggungan dalam keluarga biasanya menyebabkan jumlah pengeluaran juga semakin tinggi. Sebanyak 78 persen dari 200 petani yang dianalisis mempunyai tanggungan 1-5 orang dalam 1 keluarga. Semakin banyak jumlah tanggungan dalam keluarga akan menyebabkan petani lebih giat dalam mengusahakan usahataninya untuk meningkatkan pendapatan. Hal yang sama juga dinyatakan oleh Widyawati (2013) pada penelitian yang dilakukannya di Desa Tajuk, Kabupaten Semarang.

Tabel 6. Karakteristik Petani Kelapa Sawit menurut Kelompok Jumlah Tanggungan Keluarga

\begin{tabular}{cccc}
\hline No & Jumlah Tanggungan (Orang) & Jumlah Responden (Orang) & Persentase (\%) \\
\hline 1 & $1-5$ & 156 & 78 \\
2 & $6-10$ & 44 & 22 \\
\hline & Jumlah & $\mathbf{2 0 0}$ & $\mathbf{1 0 0}$ \\
\hline
\end{tabular}


Agriprimatech

Vol. 3 No. 2, April 2020

\section{KESIMPULAN}

Petani kelapa sawit di Kabupaten memilki karakteristik yang berbeda-beda. Berdasarkan umur sebanyak 32 persen petani berada pada rentang umur 51-55 tahun. Sebanyak 36 persen dari petani mempunyai pendidikan tertinggi pada tingkat Sekolah Dasar (SD). 100 persen petani mempunyai hak milik atas lahan yang sedang diusahakan dengan sebanyak 46 persen petani memiliki luas lahan sebesar 0-5 Hektare. Jumlah tanggungan yang dimiliki oleh petani adalah sebanyak 1-5 orang (78 Persen) dan 6-10 orang (22 persen). Sebanyak 33 persen petani telah berusahatani kelapa sawit selama 0-5 tahun.

\section{DAFTAR PUSTAKA}

Afrizon \& Herlena B. A. 2012. Karakteristik Petani Dan Pendapatan Usahatani Kakao Di Desa Surobali Kabupaten Kepahiang. Balai Pengkajian Teknologi Pertanian Bengkulu.

Emiria, F. dan H. Purwandari. 2014. Pengembangan pertanian organik di Kelompok Tani Madya, Desa Kebonagung, Kabupaten Bantul, Daerah Istimewa Yogyakarta. Jurnal Penyuluhan 10 (2).

Direktorat Jendral Perkebunan.2015. Statistik Perkebunan Indonesia. Jakarta.

Kementerian Pertanian.

Edwina, S \& Evy. M. 2014. Kajian Keragaan Karakteristik Dan Tingkat Pengetahuan Petani Tentang Sistem Integrasi Sapi Dan Kelapa Sawit (Siska) Di Kecamatan Pangkalan Lesung, Kabupaten Pelalawan. Jurnal
$e-I S S N \quad: 2621-6566$

Sepa $11(1)$.

Engel, James F, R.D Blackweel, P.J. Winiard. $1995 . \quad$ Perilaku Konsumen, Jilid 1. Jakarta: Bina Rupa aksara.

Ginanjar, G., Andayani, S.A \& Dinar. 2017. Analisis Faktor-Faktor yang Mempengaruhi Pengambilan Keputusan Petani Melakukan Usahatani Jagung Hibrida (Zea mays L). Jurnal IImu pertanian dan Peternakan, 5(02): 130-136

Joni, M.M.A, M.F.R. Rubzen, and P.J.Batt. 2001. Factors influencing a farmer's decision to purchase seed potatoes in East Java. Paper presented at the 45th Annual Conference of the Australian Agricultural and Resource Economics Society, Adelaide, South Australia.

Kotler, P. dan Kevin Lane Keller. 2007. Manajemen Pemasaran Edisi 12. Jakarta: Indeks.

Kotler, P. dan Garry Amstrong. 2016. Principles of Marketing. Pearson Education. England.

Purwanto. A. \& Budi M.T. 2018. Pengaruh Jumlah Tanggungan Terhadap Tingkat Kesejahteraan Ekonomi Keluarga Pekerja K3I Universitas Padjadjaran. Jurnal Pekerjaan Sosial 1(2)

Schiffman, and Kanuk. 2008. Perilaku KonsumenEd 7. Jakarta: PT. Indeks.

Sumarwan, U. 2010. Perilaku Konsumen. PT Ghalia Indonesia, Anggota IKAPI,Bogor. 
Agriprimatech

Vol. 3 No. 2, April 2020

Suryani, T. 2008. Perilaku Konsumen: Implikasi Pada Strategi Pemasaran. Graga IImu. Yogyakarta.

Umar, H. 2005. Riset Pemasaran dan Perilaku Konsumen. PT Gramedia Pustaka Umum. Anggota IKAPI. Jakarta
e-ISSN :2621-6566

Widyawati.F.R \& Arif. P. 2013. Pengaruh Umur, Jumlah Tanggungan Keluarga, Luas Lahan, Pendidikan, Jarak Tempat Tinggal Pekerja Ke Tempat Kerja, Dan Keuntungan Terhadap Curahan Waktu Kerja Wanita Tani Sektor Pertanian Di Desa Tajuk, Kec. Getasan, Kab. Semarang. Diponegoro Journal Of Economics 2(3). 